\title{
Bioethanol Production from Microalgae Oscillatoria sp Cultured in Blue Green 11 and Bold Basal Media
}

\author{
Hermansyah $^{1,{ }^{*}}$,Rona Ayu Sakinah ${ }^{1}$, Julinar ${ }^{1}$, Zazili Hanafiah ${ }^{2}$, and Hilda Zulkifli ${ }^{2}$ \\ ${ }^{1}$ Chemistry Department, Faculty of Mathematics and Natural Sciences, Universitas Sriwijaya, Jalan \\ Raya Palembang Prabumulih KM32, Inderalaya, South Sumatera, Indonesia 30662 \\ ${ }^{2}$ Biology Department, Faculty of Mathematics and Natural Sciences, Universitas Sriwijaya, Jalan \\ Raya Palembang Prabumulih KM32, Inderalaya, South Sumatera, Indonesia 30662 \\ *Corresponding author: Hermansyah@unsri.ac.id
}

\begin{abstract}
The third generation of bioethanol production, bioethanol converted from biomass of microalgae. Our reserach aimed to produce bioethanol from substrate microalgae Oscillatoria $s p$. as substrate has been conducted. Oscillatoria $s p$. cultured in two media namely Bold Basal and Blue Green 11. microalgae Oscillatoria sp. were cultivated in Bold Basal and Blue Green 11 media hydrolyzed substrate, $0.143 \mathrm{~mL} / \mathrm{g}$ and 0.496 $\mathrm{mL} / \mathrm{g}$, respectively. Unhyrolysate microalgae generated $0.018 \mathrm{~mL} / \mathrm{g}$ and $3.59 \mathrm{~mL} / \mathrm{g}$ of reduced sugar, respectively. Biomass obtained from Blue Green 11 media and Bold Basal media were $0.676 \mathrm{~g}$ and $0.482 \mathrm{~g}$, respectively. Based on HPLC analysis, Oscillatoria sp. biomass contained maltose. Biomass were hydrolyzed by autoclaving in $121^{\circ} \mathrm{C}$ for 15 minutes. Bioethanol production was conducted by fermentation process using Saccharomyces cerevisiae as a microbial agent which applied in hydrolysate and non-hydrolysate of microalgae. Ethanol generated from fermentation was analyzed using gas chromatography. Based on gass chromatography data resulted that hydrolysate of microalgae biomass cultivated in Bold Basal medium and in Blue Green 11 medium produced $7 \%$ and $23 \%$ ethanol, respectively.
\end{abstract}

\section{Intoduction}

The world's energy consumption has increased from 2002 to 2012. The transport sector contributes $60 \%$ of global oil consumption and responsible for $20 \%$ emissions carbon dioxide to the atmosphere [1] [2]. Biofuels have gained immense popularity in recent years as they show significant potential to replace the depleting non-renewable fuels.

Bioethanol is produced from biomass by fermentation process of carbohydrates, such as sucrose, starch and cellulose [3]. The use of first and second generation feedstocks create several problems among others, there is food versus, the highly cost of raw material, limitation of agricultural land, low production and high cost in the process of hydrolisis which makes the material less effective and difficult to be commercialized [2].

\footnotetext{
*Corresponding author: Hermansyah@unsri.ac.id
} 
Microalgae are classified as third generation feedstocks [4]. Microalgae are microscopic photosynthetic organism, many of which are unicellular. Microalgae are found in both fresh and marine water. Microalgae which have high amount of carbohydrates are very useful for bioethanol production. The advantages of using microalgae include rapid growth, high productivity, both freshwater and seawater may be used, they also not compete with food and the production cost is relatively low $[3,5]$.

Cyanobacteria, such as Oscillatoria sp., are a ubiquitous group of bacteria [6] found in freshwater systems. Research utilizing Oscillatoria $s p$. has been widely used its bioactive compounds as antibacterial, antioxidant, antibiofilm, biofertilizer, etc. Carbohydrates contained in microalga Oscillatoria sp. about $19.3 \%$ [3], it can be used as bioethanol feedstock through fermentation process by utilizing the capability of Saccharomyces cerevisiae. The cultivation process of Oscillatoria sp. can use growth media such as Basal Bold Media and Blue Green 11 media.

Based on the content of carbohydrates and the ability to grow, this research is aimed to know the potential of bioethanol production with microalgae Oscillatoria sp. as substrate through fermentation process using yeast Saccharomyces cerevisiae.

\section{Materials and Methods}

\subsection{Materials}

The raw materials used in this research are: Oscillatoria sp., cultured at the Integrated Research Laboratory of Sriwijaya University Graduate Program, yeast strain SH5209 Saccharomyces cerevisiae, yeast extract, peptone, dextrose, bacto agar, ammonium sulphate, magnesium sulphate, potassium dihydrogen phosphate, sulfuric acid, $\mathrm{NaNO}_{3}$, $\mathrm{K}_{2} \mathrm{HPO}_{4}, \mathrm{MgSO} 4.7 \mathrm{H}_{2} \mathrm{O}, \mathrm{CaCl}_{2} .2 \mathrm{H}_{2} \mathrm{O}$, Citric acid, Ammonium ferric citrate green, EDTA $\mathrm{Na}_{2}, \quad \mathrm{Na}_{2} \mathrm{CO}_{3}, \quad \mathrm{H}_{3} \mathrm{BO}_{3}, \quad \mathrm{MnCl}_{2} .4 \mathrm{H}_{2} \mathrm{O}, \quad \mathrm{ZnSO} \mathrm{n}_{4} .7 \mathrm{H}_{2} \mathrm{O}, \mathrm{NaCl}, \mathrm{KOH}, \mathrm{Na} 2 \mathrm{MoO}_{4} .2 \mathrm{H}_{2} \mathrm{O}$, $\mathrm{CuSO}_{4} .5 \mathrm{H}_{2} \mathrm{O}, \mathrm{Co}\left(\mathrm{NO}_{3}\right)_{2} .6 \mathrm{H}_{2} \mathrm{O}, \mathrm{MoO}_{3}$, EDTA, $\mathrm{FeSO}_{4} .7 \mathrm{H}_{2} \mathrm{O}$, ethanol standard and aquades.

\subsection{Cultivation of Microalgae Oscillatoria sp. in Blue Green 11 media [7]}

Preparation of BG 11 media consists of making stock solution and trace element solution. Blue Green 11 stock solution was dissolved in $500 \mathrm{~mL}$ distilled water with the following composition, $75 \mathrm{~g} \mathrm{NaNO}_{3}, 2 \mathrm{~g} \mathrm{~K}_{2} \mathrm{HPO}_{4}, 3.75 \mathrm{~g} \mathrm{MgSO}_{4} .7 \mathrm{H}_{2} \mathrm{O}, 1.8 \mathrm{~g} \mathrm{CaCl}_{2} .2 \mathrm{H}_{2} \mathrm{O}$, $0.30 \mathrm{~g}$ Citric Acid, $0.30 \mathrm{~g}$ Ammonium ferric citrate green, $0.05 \mathrm{~g} \mathrm{NaEDTA}, 1 \mathrm{~g} \mathrm{Na} \mathrm{CO}_{3}$. The trace metal solution was prepared as 1 liter with the following composition, $2.86 \mathrm{~g} \mathrm{H}_{3} \mathrm{BO}_{3}$, $1.8 \mathrm{~g} \mathrm{MnCl}_{2} .4 \mathrm{H}_{2} \mathrm{O}, 0.22 \mathrm{~g} \mathrm{ZnSO}_{4} .7 \mathrm{H}_{2} \mathrm{O}, 0.39 \mathrm{~g} \mathrm{Na}_{2} \mathrm{MoO}_{4} .2 \mathrm{H}_{2} \mathrm{O}, 0.08$ g CuSO $4.5 \mathrm{H}_{2} \mathrm{O}, 0.05$ $\mathrm{g} \mathrm{Co}\left(\mathrm{NO}_{3}\right)_{2} \cdot 6 \mathrm{H}_{2} \mathrm{O}$. Biomass production was performed with $10 \mathrm{~mL}$ of stock solution and 1 $\mathrm{mL}$ of trace metal solution was added into $1 \mathrm{~L}$ of distilled water. Set the $\mathrm{pH}$ of the solutionup to 7.1 with $1 \mathrm{M} \mathrm{HCL}$ or $\mathrm{NaOH}$. Then it was autoclave at $121^{\circ} \mathrm{C}$ for 15 minutes. Then added $1 \mathrm{~mL}$ of culture seed Oscillatoria sp. and culture using light intensity, temperature $30^{\circ} \mathrm{C}$ with aeration continuously.

\subsection{Cultivation of Microalgae Oscillatoria sp. In Bold Basal Media [8]}

Preparation BB media consists of making stock solution and trace element solution. The Bold Basal stock solution was dissolved in $400 \mathrm{~mL}$ distilled water with the following composition, $10.0 \mathrm{~g} \mathrm{NaNO}_{3}, 3.0 \mathrm{~g} \mathrm{MgSO}_{4} .7 \mathrm{H}_{2} \mathrm{O}, 1.0 \mathrm{~g} \mathrm{NaCl}, 3.0 \mathrm{~g} \mathrm{~K}_{2} \mathrm{HPO}_{4}, 7.0 \mathrm{~g} \mathrm{KH}_{2} \mathrm{PO}_{4}$, $1.0 \mathrm{~g} \mathrm{CaCl}_{2} \cdot 2 \mathrm{H}_{2} \mathrm{O}$. Trace metal solution was prepared as 1 liter with the following 
composition, $8.82 \mathrm{~g} \mathrm{ZnSO}_{4} .7 \mathrm{H}_{2} \mathrm{O}, 1.44 \mathrm{~g} \mathrm{MnCl}_{2} .4 \mathrm{H}_{2} \mathrm{O}, 0.71 \mathrm{~g} \mathrm{MoO}_{3}, 1.57 \mathrm{~g} \mathrm{CuSO}_{4} .5 \mathrm{H}_{2} \mathrm{O}$, $0.49 \mathrm{~g} \mathrm{Co}\left(\mathrm{NO}_{3}\right)_{2} .6 \mathrm{H}_{2} \mathrm{O}, 11.42 \mathrm{~g} \mathrm{H}_{3} \mathrm{BO}_{3}, 50 \mathrm{~g}$ EDTA, 31g KOH, 4.98g FeSO $4.7 \mathrm{H}_{2} \mathrm{O}, 1.0 \mathrm{~mL}$ $\mathrm{H}_{2} \mathrm{SO}_{4}$ (conc). Biomass production was performed with $10 \mathrm{~mL}$ of stock solution and $1 \mathrm{~mL}$ of trace metal solution was introduced into $1.0 \mathrm{~L}$ of distilled water. Then sterilized using autoclave at $121^{\circ} \mathrm{C}$ for 15 minutes. Then added $1.0 \mathrm{~mL}$ of culture seed Oscillatoria sp. and in culture using light intensity, temperature $30^{\circ} \mathrm{C}$ with aeration continuously. Fermentation media consisted of $2 \mathrm{~g}$ yeast extract, $2.0 \mathrm{~g}\left(\mathrm{NH}_{4}\right)_{2} \mathrm{SO}_{4}, 2.0 \mathrm{~g} \mathrm{MgSO} \mathrm{g}_{4}, 4.0 \mathrm{~g} \mathrm{KH}_{2} \mathrm{PO}_{4} 4$ dissolved in $100 \mathrm{~mL}$ distilled water erlenmeyer dissolved.

\subsection{Determination of Carbohydrate Content [9]}

Dried biomass about $25 \mathrm{mg}$ are inserted into centrifugation tubes, then added $2.5 \mathrm{~mL}$ of sterile water incubated at $90^{\circ} \mathrm{C}$ for $10 \mathrm{~min}$. Sample was vortexed for $7 \mathrm{x} 2.0 \mathrm{~min}$, then finally carbohydrate content of extract was measured using HPLC.

\subsection{Hidrolysis of Microalgae Oscillatoria sp.}

Hydrolysis dried biomass Oscillatoria $s p$. is done by adding $0.2 \mathrm{~g}$ into $15 \mathrm{~mL}$ of distilled water, then heated by autoclaving at $121^{\circ} \mathrm{C}$ at 1 atm for $20 \mathrm{~min}$. Reducing sugar content was analysed using 3,5-dinitrosalicylic acid (DNS) method [10].

\subsection{Fermentation Process}

The bioethanol fermentation carried out with the following composition, $2 \mathrm{~mL}$ biomass Oscillatoria sp., $2 \mathrm{~mL}$ of inoculum S.cerevisiae, and $25 \mathrm{~mL}$ of fermentation media incubated with shaking $30 \mathrm{rpm}$ at $30^{\circ} \mathrm{C}, 30 \mathrm{rpm}$.

While the bioethanol fermentation dried biomass Osillatoria $s p$. without hydrolysis process is carried out with the following composition as biomass Oscillatoria sp. $0.1 \mathrm{~g}, 2$ $\mathrm{mL}$ of inoculum media, and $25 \mathrm{~mL}$ of fermentation media. Fermentation is carried out for 4 days with every day interval taken $2 \mathrm{~mL}$ of solution to analyze ethanol content using Gas Chromatography.

\section{Results and Discussions}

\subsection{Biomass Oscillatoria sp. in Growing Media Bold Basal and Blue Green 11}

The process of cultivating microalga Oscillatoria sp. is done in two different media: Bold Basal and Blue Green 11. Bold Basal and Blue Green 11 are selective media for microalgae especially from division of Cyanophyta or blue green algae. The cultivation process is carried out in two different culture to produce biomass and see the comparison biomass product that can be used for further analysis. 


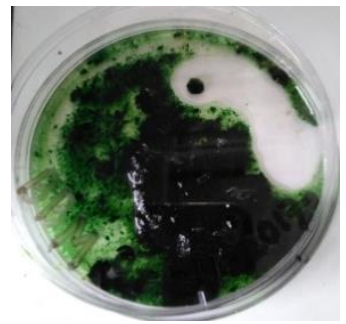

(a)

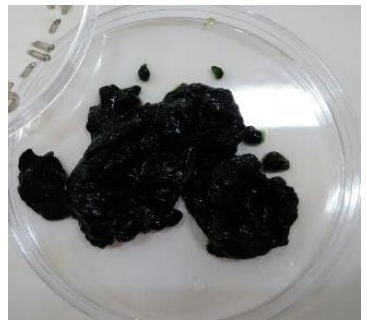

(b)

Fig. 1. Wet biomass microalgae Oscillatoria sp. in media cultivation (a). Bold Basal (b). Blue Green 11

Harvesting of microalgae Oscillatoria sp. done at the stationary phase. Stationary phase is a phase of constant growth in which the reproduction rate equal to the rate of mortality. Cell division still occurs in stationary phase, this is because cells reserves energy for cell division and growth [11]. The harvesting process used separation method by centrifugation at $4000 \mathrm{rpm}$ for 5 minutes. The advantages using this method on a laboratory scale has been tested and obtain high concentration of about 12-22\%. In Figure. 1, shows wet biomass from microalga Oscillatoria sp. Wet biomass obtained in figure.1(a) is $9.49 \mathrm{~g}$, figure.1(b) $10.27 \mathrm{~g}$ biomass.

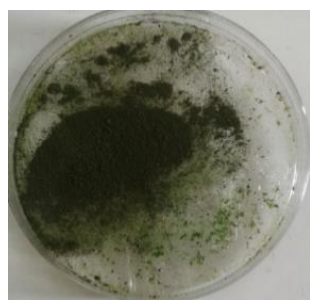

(a)

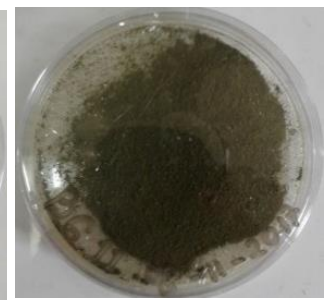

(b)

Fig. 1. Dried biomass of microalgae Oscillatoria sp. cultivated in media (a). Bold Basal (b). Blue Green 11

Preparation of microalgae Oscillatoria $s p$. is done by drying the biomass in the oven at $35^{\circ} \mathrm{C}$ for a day. Dried biomass, the solid green, is shown in Figure 2, which obtained $0.48 \mathrm{~g}$ in figure2(a) and figure2(b) $0.68 \mathrm{~g}$. organic sources in microalgae growing can be obtained from wastewater containing amino acids, phosphorus, and potassium

\subsection{Water Content of Biomass Microalgal Oscillatoria sp.}

Determination of moisture content is done by evaporating wet biomass in the oven at low temperatures. Water content from biomass microalgae Oscillatoria sp. shown in Table 1.

Table 1. Water content of biomass Oscillatoria sp.

\begin{tabular}{|c|c|c|}
\hline $\begin{array}{c}\text { Cultivation } \\
\text { media }\end{array}$ & Biomass & $\begin{array}{c}\text { Water content } \\
(\mathbf{\%})\end{array}$ \\
\hline \multirow{2}{*}{ Bold Basal } & Wet & $94,92 \%$ \\
\cline { 2 - 3 } & Dried & $5,08 \%$ \\
\hline \multirow{2}{*}{ Blue Green 11 } & Wet & $93,42 \%$ \\
\cline { 2 - 3 } & Dried & $6,58 \%$ \\
\hline
\end{tabular}




\subsection{Simple Sugar Content of Microalgae Oscillatoria sp.}

Type of carbohydrates on the substrate of the two cultures of culture media is maltose. The maltose standard appears as a peak at a retention time of 4.525 minutes with concentration of $160 \mathrm{ppm}$. Substrate from Bold Basal media appeared as peak with a retention time 4.732 minutes with an area of 50757 while from Blue Green 11 media was at the peak with a retention time of 4.737 minutes and wide area of 46710 . The substrate concentration of HPLC measurements was obtained sequentially as much as $167 \mathrm{ppm}$ and of $154 \mathrm{ppm}$. Other saccharides appeared as peak in the chromatogram which possibly is composing structure of microalga Oscillatoria $s p$. and its existence can not be identified yet.

\subsection{Determination Concentration of Reducing Sugar Content}

Determination of reducing sugar content is done by reacting the sample with a reagent. Then the solution was analyzed by the spectrophotometric method at $540 \mathrm{~nm}$ wavelength. The absorbance values obtained from the analysis using spectrophotometry were inserted into the linear equations on the glucose standard curve. Figure 3 and 4 have shown the graph of reducing sugar content by the DNS method.

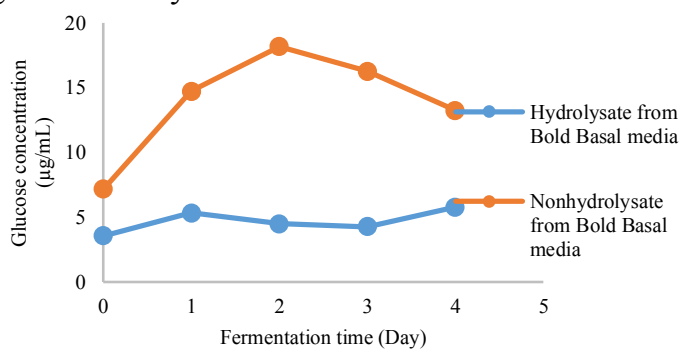

Fig. 3. Glucose content from hydrolysate and nonhydrolisate Oscillatoria sp. cultivated from Bold Basal media

Based on Figure 4 shows the sugar content before fermentation as much as $3.55 \mu \mathrm{g} / \mathrm{mL}$. On the first day the reducing sugar level of $5.33 \mu \mathrm{g} / \mathrm{mL}$ decreased on $2^{\text {nd }}$ and $3^{\text {rd }}$ day 4.49 $\mu \mathrm{g} / \mathrm{mL}$ and $4.28 \mu \mathrm{g} / \mathrm{mL}$ respectively. The highest reducing sugar content, $5.78 \mu \mathrm{g} / \mathrm{mL}$, was obtained in the $4^{\text {th }}$ day. Another graph within the orange line shows the glucose levels of the substrate was not hydrolyzed. The reducing sugar on the $2^{\text {nd }}, 3^{\text {rd }}$, and $4^{\text {th }}$ day were 18.17 $\mu \mathrm{g} / \mathrm{mL}, 16.27 \mu \mathrm{g} / \mathrm{mL}$, and $13.24 \mu \mathrm{g} / \mathrm{mL}$, sequently.

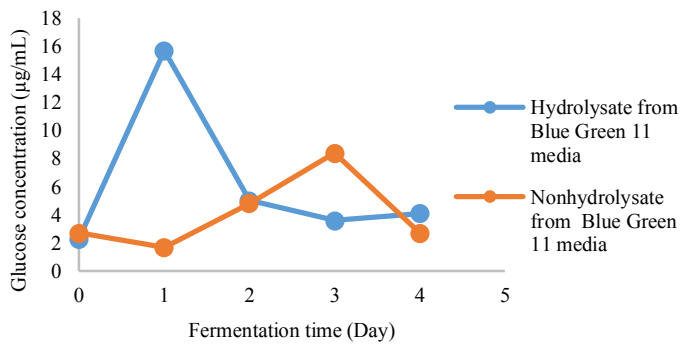


Fig. 4. Reducing sugar content from hydrolysate and nonhydrolisate Oscillatoria sp. from Blue Green 11 media

Microalgae Hydrolysis of Blue Green medium 11 in Figure 5 shows the largest sugar content obtained on the first day with a total of $15.69 \mu \mathrm{g} / \mathrm{mL}$. Glucose before fermentation level of $2.29 \mu \mathrm{g} / \mathrm{mL}$. Thereafter decreased on the $2^{\text {nd }}$ day by $5.02 \mu \mathrm{g} / \mathrm{mL}$, and the $3^{\text {rd }}$ day $3.60 \mu \mathrm{g} / \mathrm{mL}$, on the $4^{\text {th }}$ day there was a slight increase of $4.08 \mu \mathrm{g} / \mathrm{mL}$. While the sugar content on the same medium but the substrate without hydrolysis obtained a small amount, with the optimum value on the $3^{\text {rd }}$ day of fermentation with a total of $8.39 \mu \mathrm{g} / \mathrm{mL}$. Glucose levels before fermentation were $2.71 \mu \mathrm{g} / \mathrm{mL}$ and increased from day 1 to $1.68 \mu \mathrm{g} / \mathrm{mL}$, and the $2^{\text {nd }}$ day was $4.82 \mu \mathrm{g} / \mathrm{mL}$ and started to decline on the $4^{\text {th }}$ day with glucose levels of 2.71 $\mu \mathrm{g} / \mathrm{mL}$.

Sugar becomes the main source of carbon needed for the growth of microorganisms and synthesizes the energy. The decrease in sugar is not only converted by yeast to ethanol but also utilized by yeast for cell growth, intracellular metabolism such as enzyme synthesis, DNA and so on [12]. The amount of sugar needed for yeast metabolism varies from each strain. At low concentrations of substrate, yeast will starve and productivity decrease.

\subsection{Bioethanol Content in the Variation of Fermentation Time in Bold Basal Media}

Based on chromatogram analysis by comparing ethanol standard and sample, ethanol content from substrate Oscillatoria sp. in Bold Basal media with hydrolysis and non hydrolysis treatment shown in Figure 5.

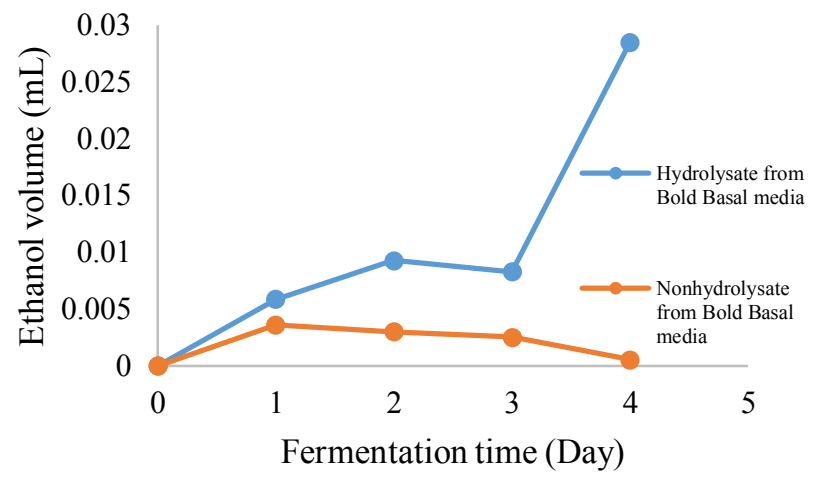

Fig. 5. Bioethanol content in the variation fermentation time microalgal Oscillatoria sp. from Bold Basal (Hydrolysis) dan (Non Hydrolysis) medil

Substrates Oscillatoria $s p$. which hydrolyzed had the greatest conversion value on the fourth day of fermentation with $0.029 \mathrm{~mL}$ ethanol volume. In other graph shows substrate fermentation of the Bold Basal media which is not hydrolysed. The optimum condition of ethanol production was obtained at the time of fermentation on the first day with ethanol $0.0036 \mathrm{~mL}$. Further there was a significant decrease in ethanol content. This suggests that the ethanol content of the hydrolysed substrate is greater than that of nonhydrolysis due to maltose on the microalgae has been broken down into simple sugars, the glucose molecule. The second and third day fermentation times indicate that the yeast stage is in the stationary phase indicating that yeast is not working optimally. During the fourth day of fermentation the resulting bioethanol content decreases and tends to be constant. 


\subsection{Bioethanol production on the Variation of the Fermentation Time in Blue Green 11 Media}

Based on chromatogram analysis by comparing ethanol standard and samples obtained ethanol content from microalgae in growth media of Blue Green 11 with hydrolysis and non hydrolysis treatment as shown in Figure 6.

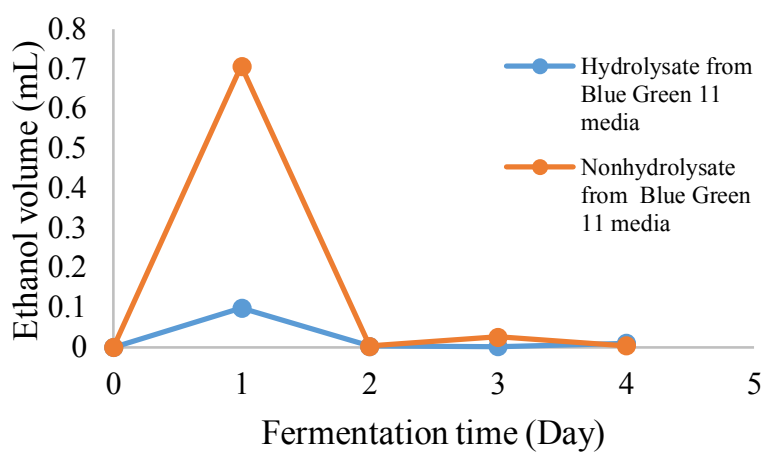

Fig. 6. Bioethanol content in the variation fermentation time microalgal Oscillatoria sp. from Blue Green 11 (Hydrolysis) dan (Non Hydrolysis) media

Based on the graph of bioethanol content of Blue Green 11 medium showed the same optimum conditions at first day fermentation with ethanol content of $0.099 \mathrm{~mL}$ and 0.708 $\mathrm{mL}$ respectively. This may be due to the low amount of fermented substrate converted entirely on the first day, the consumption of sugar by yeast then decreases because the amount of sugar left utilized by yeast for cell growth as a carbon source. The graph showing the ethanol volume of the unscreened sample showed a high purity so that the resulting volume was larger, but ethanol was not purified first so there should still be impurities or other residues affecting the chromatogram formed. This can be caused by the effect of the duration of storage on ethanol content. Storage time in the refrigerator can affect the increase in ethanol content. This is because in low temperature will inhibit yeast growth. However, cooling can not stop the metabolism activity of microorganisms, with the cooling treatment metabolism activity will take place somewhat slowly which is marked by decreased growth rate.

Based on the difference of treatment on microalgae substrate, obtained the optimum value from substrate Bold Basal and Blue Green 11 media which has been hydrolysis first. Saccharomyces cerevisiae has the ability to break down hexose sugar like glucose. The microalgae substrate has a sugar content of maltose composed of two glucose molecules, so it is necessary to pretreatment the susbtrat in the form of hydrolysis to break down the sugar of maltose into glucose to produce a higher ethanol content. Pretreatment performed is physically hydrolysed by heating at a temperature of $121^{\circ} \mathrm{C}$ for 20 minutes. Physically pretreatment using autoclave means able to produce large amount of carbohydrate [13].

\section{Conclusions}

1. Based on the results of carbohydrate analysis using HPLC simple sugar content microalga Oscillatoria sp. in the culture media Bold Basal and Blue Green 11 are maltose. 
2. Microalga Oscillatoria sp. producing ethanol of $0.143 \mathrm{~mL} / \mathrm{g}$ and $0.496 \mathrm{~mL} / \mathrm{g}$ respectively from the microalgae hydrolyzate in Bold Basal and Blue Green culture medium 11, whereas $0.018 \mathrm{~mL} / \mathrm{g}$ and $3.59 \mathrm{~mL} / \mathrm{g}$ respectively from nonhydrolysis substrate in culture medium Bold Basal and Blue Green 11.

3. Yield bioethanol from cultivation media obtained $7 \%$ (Hydrolysis) dan $8 \%$ (Nonhydrolysis) and from Blue Green 11 media yield obtain 23\% (Hydrolysis) dan 6\% (Nonhydrolysis).

\section{Acknowledgments}

Authors thank Universitas Sriwijaya through "PNBP Hibah Profesi 2017" contract number 987/UN9.3.1/PP/2017 for support this research.

\section{References}

1. R. Harun, W.S. Jason, S. Thiruvenkadam, W.A. Ghani, T. Cherrington, M.K. Danquah, t. J. Biotechnol 9, 73 (2013)

2. A.R. Sirajunnisa, S. Duraiarasan. J. Renew. and Sust. Energ. Rev 66, 248 (2016)

3. R.P. John, G.S. Anisha., K.M Nampoothiri, A. Pandey. J. Bioresour. Technol 102, 168 (2011)

4. L Assadad, B.S.B. Utomo, R.N. Sar. J. Squalen 5, 51 (2010).

5. L. Chaudhary, P. Pradhan, N.Soni, P. Singh, A. Tiwari, Int. J. ChemTech Res 6, 1381 (2014)

6. M. Swanson-Mungerson, R. Incrocci, V. Subramaniam, P. Williams, M.L., Hall, A.M.S. Mayer. J. Toxicol. Lett 275,101 (2017)

7. R.Y. Stanier, R. Kunisawa, M. Mandel, G. Cohen-Bazire G. J. Bacteriol. Rev. 35, 171( 1971)

8. R.A. Andersen, Algal culturing techniques (London: Elsevier Academic Press, 2005)

9. G. Zhao, C. Xue, W. Lei W, S.Zhao, H. Feng, W.N. Chen, R. Lau, J. Bioresour Technol. 138, 337 (2013)

10. D.Y.R. Sari, T.B. Saputro, A. Muhibuddin, Jurnal Sains dan Seni ITS. 5, 2337 (2015)

11. S.K. Bariyyah, A.G. Fasya, A. M.Abidin, Hanapi, J. Alchemy 2, 199 (2013)

12. D. Oczimen, B. Inan, J. Intech open science: Biofuels-Status and Respective 7, 142 (2014)

13. H.M. Kim, S.G. Wi, S. Jung, Y. Song, H.J. J. Bae Bioresour Technol 101, 128 (2014) 